\title{
The Role of Immune Cells in the Pathogenesis of Idiopathic Inflammatory Myopathies
}

\author{
Lijuan Zhao', Qi Wang², Bin Zhou ${ }^{3}$, Lihua Zhang ${ }^{4}$, Honglin Zhu ${ }^{\text {* }}$ \\ ${ }^{1}$ Department of Rheumatology, Xiangya Hospital, Central South University, Changsha, Hunan, China. \\ ${ }^{2}$ Department of Radiology, Hunan Provincial People's Hospital and The First Affiliated Hospital of Hunan \\ Normal University, Changsha, Hunan, China. \\ ${ }^{3}$ Department of Nephrology, The Affiliated Hospital of Qingdao University, Qingdao, China. \\ ${ }^{4}$ Department of Rheumatology, Hunan Provincial People's Hospital and The First Affiliated Hospital of Hunan \\ Normal University, Changsha, Hunan, China.
}

[Received February 17, 2020; Revised April 8, 2020; Accepted April 10, 2020]

\begin{abstract}
Idiopathic inflammatory myopathies (IIMs) are chronic autoimmune disorders involving multiple organs, such as the muscle, skin, lungs and joints. Although the detailed pathogenesis of IIMs remains unclear, immune mechanisms have long been recognised as of key importance. Immune cells contribute to many inflammatory processes via intercellular interactions and secretion of inflammatory factors, and many studies have demonstrated the participation of a variety of immune cells, such as $T$ cells and $B$ cells, in the development of IIMs. Here, we summarise the current knowledge regarding immune cells in IIM patients and discuss their potential roles in IIM pathogenesis.
\end{abstract}

Key words: Idiopathic inflammatory myopathies, immune cells, pathogenesis

\section{Introduction}

Idiopathic inflammatory myopathies (IIMs) comprise a group of heterogeneous rheumatic diseases predominantly characterised by progressive muscle weakness and reduced muscle endurance [1-4]. In addition to muscles, multiple other organs, such as the skin, lungs and joints, may be involved. The main subgroups of IIMs include dermatomyositis (DM), polymyositis (PM), inclusion body myositis (IBM) and immune-mediated necrotising myopathy (IMNM) [5, 6]. Treatment with high doses of glucocorticoids combined with immunosuppressive agents has largely improved the prognosis of IIMs, yet a considerable proportion of patients respond poorly and develop sustained muscle weakness [7, 8]. In general, a comprehensive understanding of IIM pathogenesis is needed for optimal therapeutic intervention.

Over the past decade, researchers have mainly focused on immune mechanisms in the development of IIMs due to the evidence regarding quantitative as well as qualitative abnormalities of immune cells in tissues and in the circulation for almost all types of IIMs [9, 10]. Lymphocytes are an important class of immune cells that are subdivided into T cells, B cells and natural killer (NK) cells. T cells and B cells are major components of adaptive immunity, recognising specific antigens and generating specific cell-mediated or antibody-mediated responses

*Correspondence should be addressed to: Dr. Honglin Zhu, Department of Rheumatology, Xiangya Hospital, Central South University, Hunan 410008, China E-mail address: honglinzhu@csu.edu.cn.

Copyright: $\odot 2020$ Zhao L et al. This is an open-access article distributed under the terms of the Creative Commons Attribution License, which permits unrestricted use, distribution, and reproduction in any medium, provided the original author and source are credited. 
[11]. NK cells participate in innate immunity and function by releasing immunomodulatory cytokines or cytotoxic granules following their activation [12]. Other innate immune cells mainly include dendritic cells and macrophages, which initiate and support local immune responses by processing and presenting antigens [13]. In addition, mesenchymal stem cells and low-density granulocytes exhibit unique immunologic functions [14, 15]. Here, we discuss recent insight into the possible roles of these immune cells and highlight their intrinsic value as therapeutic targets in IIMs.

\section{T cells in IIMs}

T cells complete their primary development in the thymus and then enter the recirculation between the bloodstream and secondary lymphoid tissues [16]. Before they encounter specific antigens, mature recirculating $T$ cells are known as naïve $\mathrm{T}$ cells. Once stimulated by antigenpresenting cells in a human leukocyte antigen (HLA)dependent manner, $\mathrm{T}$ cells proliferate and differentiate into effector $\mathrm{T}$ cells or memory $\mathrm{T}$ cells [17]. There are several functional classes of effector $\mathrm{T}$ cells, which are specialised for different activities. CD8+ T cells recognise antigen peptides presented by HLA class I molecules, and their effector counterparts cytotoxic T cells (CTLs) have the ability to kill target cells [18]. After identifying the peptide:HLA complex on the surface of antigenpresenting cells, CD4+ $\mathrm{T}$ cells generate a flexible repertoire of effector subsets, including $\mathrm{T}$ helper (Th) cells, $\mathrm{T}$ follicular helper (Tfh) cells and regulatory $\mathrm{T}$ cells (Tregs); Th cells and Tfh cells activate target cells, whereas Tregs have a substantial immunosuppressive function [19].

$\mathrm{T}$ cells of diverse lineages have been implicated in the pathogenesis of IIMs [20]. CTLs produce toxic granules called perforins and granzymes, causing injury to myofibers that express morbidly increased amounts of HLA class I molecules [21, 22]. These CD8+ T cells often clonally expand in both diseased muscles and peripheral blood [23-26]. Additionally, Th cells orchestrate amplifying immune responses by secreting various cytokines [27, 28] and assist in antibody production by providing costimulatory signals [29]. Tregs inhibit the lytic activity of myo-reactive CD8+ cells and are proposed to play a role in counterbalancing muscle inflammation [30]. In a previous study, indirect proof of complete remission with renewal and diversification of the Treg compartment in two juvenile DM patients treated with autologous hematopoietic stem cell transplantation (HSCT) was obtained [31]. Furthermore, some special subtypes of $\mathrm{T}$ cells induce the breakdown of immune tolerance and further initiate the development of autoimmunity.

\subsection{Muscle-infiltrating T cells}

Because normal muscles rarely show immune cell infiltration, there have been efforts to elucidate how these cells migrate into muscles in IIMs. For example, chemokines produced by existing inflammatory cells or muscle fibres have been suggested to be involved in sustaining the trafficking of these cells [32]. Additionally, disrupted vascular permeability resulting from the deposition of complement membrane attack complexes [33], cleavage of endothelial VE-cadherin by upregulated neutrophil serine proteinases $[34,35]$ and other factors can facilitate immune cell invasion. It is currently accepted that CD8+ $\mathrm{T}$ cells are more abundant near the endomysium in PM and IBM but that CD4+ T cells are more common in perivascular regions around the perimysium in DM [33].

\section{CD28null T cells}

Naïve T cells express CD28 as a costimulatory molecule for antigen-driven activation and proliferation [36, 37]. The frequency of CD28null $\mathrm{T}$ cells increases with the progressive differentiation of central memory $\mathrm{T}$ cells due to repeated antigen stimulation, although the mechanism has yet to be clarified [38, 39]. In vitro experiments indicate that TNF- $\alpha$ down-regulates $\mathrm{T}$ cell $\mathrm{CD} 28$ expression at the transcriptional level by inhibiting the activity of its minimal promoter [40]. A reduction in CD28 expression is thought to cause rapid immune responses independent of interactions with professional antigen-presenting cells when re-challenge with the same pathogen occurs [41]. In comparison with conventional CD28+ T cells, CD28null $\mathrm{T}$ cells are hypersensitive and can release large amounts of cytokines as well as cytolytic granules [42, 43]. Moreover, CD28null $\mathrm{T}$ cells are compromised with regard to antigen receptor diversity, antigen-induced proliferation and replicative lifespan [44]. It is reasonable that more CD28null $\mathrm{T}$ cells accumulate in elderly individuals because these individuals have experienced more antigenic stimulation [38]. In various chronic inflammatory processes, including viral infections and autoimmunity (such as Graves' disease, ankylosing spondylitis and rheumatoid arthritis), CD28null T cells show expanded populations $[45,46]$ and confer cytotoxicity towards affected tissues [47].

CD28null T cells are increased in the muscle as well as the circulation of DM/PM patients, especially those seropositive for human cytomegalovirus. As the dominating $T$ cell subsets of muscle infiltrates, the existence of CD28null T cells may be traced back to the time of diagnosis, and these cells persist during later disease stages [48]. High frequencies of CD28null T cells 
have also been found in muscle infiltrates and the circulation of IBM patients. Compared with peripheral blood, higher frequencies of CD28null T cells are present in inflamed muscle, indicating active recruitment, local proliferation or preferential retention of CD28null T cells in the tissue. Although these CD28null T cell populations are restricted in their $\mathrm{T}$ cell receptor (TCR) $\mathrm{V}_{\beta}$ usage, they are functionally non-senescent, with high interferon (IFN)- $\gamma$ secretion and degranulation potential [49]. In PM, CD28null T cells, either CD4+ or CD8+, are capable of inducing a greater degree of muscle cell death than are their CD28+ counterparts[50]. To some extent, this may be attributed to polarised perforins because suppression of this process obviously reduces CD28null $\mathrm{T}$ cell cytotoxicity. In addition to perforins, the high level of IFN- $\gamma$ secreted by CD28null T cells robustly up-regulates HLA (both class I and II) in muscles. Furthermore, interactions between TCR and HLA are required for the activation of CD28null $\mathrm{T}$ cells $[42,51]$, indicating the persistent destructiveness of CD28null $\mathrm{T}$ cells towards muscle fibres through a positive feedback loop. Interestingly, myotubes present greater sensitivity to CD28null $\mathrm{T}$ cell lethality than do myoblasts, possibly owing to muscle-specific antigens during differentiation [50]. Another characteristic of CD28null T cells is their anti-apoptotic property. Specifically, the proliferation and function of CD28null $\mathrm{T}$ cells are only partly suppressed by glucocorticoids and Tregs in DM/PM patients [52], which may be explained by the imbalance of antiapoptotic proteins and pro-apoptotic molecules [53, 54]. For this reason, CD28null T cells persist in muscle tissue in many patients with DM/PM, who regain less than $75 \%$ of functional index even while responding well to conventional immunosuppressive treatment. In addition, a negative correlation between post-treatment CD28null $\mathrm{T}$ cells and comparatively poor outcomes has been validated [52].

\section{Highly differentiated cytotoxic T cells}

The refractoriness of some IIM patients towards corticosteroids and immunosuppressive agents hints at a specific nature of autoimmunity that conventional therapies cannot address [55]. In a genome-wide study of gene expression comparing muscle samples from IBM and other myopathies, a signature of highly differentiated cytotoxic CD8+ T cells (effector memory cells (TEMs) and terminally differentiated effector memory cells (TEMRAs)) was identified. Killer cell lectin-like receptor G1 (KLRG1), a marker of this population of cells, coexpresses with cytotoxic genes, and KLRG1+ cells were found to be abundant in IBM muscle, with a pattern of multifocal myofiber infiltration and invasion. Their circulating counterparts also account for a higher proportion of lymphocytes and CD8+ $\mathrm{T}$ cells in the peripheral blood of IBM patients [56]. These findings are in line with previous studies on CD28null T cells because $\mathrm{T}$ cells lacking CD28 are antigen experienced and highly differentiated [38].

\section{T cells with special surface molecules}

CD4+ and CD8+ $\mathrm{T}$ cells exhibit unique phenotypes depending on the expression of surface markers. CD45RO and CD45RA are two different isoforms of CD45. When expressed by $\mathrm{T}$ cells, CD45RO indicates antigen priming, whereas CD45RA represents an unprimed status [57]. $\mathrm{CD} 45 \mathrm{RO}+\mathrm{T}$ cells, but not CD45RA+ $\mathrm{T}$ cells, predominate in DM/PM perivascular accumulation and in IBM/PM endomysial accumulation, and possible participation of these cells in muscle pathogenesis through an enhanced capacity of transendothelial migration or virgin-to-memory conversion occurring after diapedesis has been proposed [58]. NKG2D (naturalkiller group 2, member D) is mainly expressed on the surface of NK cells. In a minority of cases, CD8+ T cells express NKG2D and gain the capacity to directly target cells independent of TCR. Chronic stimulation by IL-15 is a key mechanism in the acquisition of this capacity [59, 60]. In PM, muscle cells show predominantly higher expression of the NKG2D ligand MICA/B and membrane-related IL-15. In vitro, myoblast (treated with IFN $\gamma$ and $\mathrm{TNF} \alpha$ )-derived IL-15 is able to convert naïve CD8+ $\mathrm{T}$ cells into highly activated cytotoxic CD8+NKG2Dhigh $\mathrm{T}$ cells and maintain a proinflammatory environment [61]. Inducible co-stimulatorligand (ICOS-L) belongs to the B7-family and is usually expressed on monocytes or dendritic cells. After interacting with its receptor ICOS on T cells, ICOS-L promotes Th1 and Th2 responses [62, 63]. ICOS-L was found to be abnormally expressed by IBM myofibers, and a class of autoinvasive CD8+ T cells expressing ICOS in inflamed muscles was detected. Moreover, ICOS.ICOSL co-stimulatory signalling is associated with upregulated effector perforin levels and may reflect the degree of endomysial inflammation [64]. CCR7 is the receptor for the chemokine CCL19, and both are very important in the homing and priming of $\mathrm{T}$ cells [65]. Without inflammation, the chemokine system is seldom expressed in muscles, but in PM and IBM, CCR7+ T cells preferentially surround and invade nonnecrotic muscle fibres positive for CCL19 [66, 67]. CXCL12 is another chemokine that acts as a ligand for CXCR4, and it has been suggested that their interaction helps recruit stem cells to tissues in need of repair [65]. A significantly high frequency of IL-4-producing CXCR4+ Th2 T cells has been documented in the muscles of DM/PM patients. Consistently, a high level of CXCL12 expression is 
observed in the vascular endothelial cells of muscle tissue. Furthermore, the number of CXCR4+ T cells correlates inversely with serum creatinine kinase (CK) and lactate dehydrogenase (LDH) levels [68]. These findings suggest possible roles for the above surface molecules during myositis progression, even though the mechanism and downstream events remain to be elucidated.

\section{Biased cytokine expression reflecting $T$ cell responses in muscles}

Cytokines have important functions in inflammatory processes. Local release of $\mathrm{T}$ cell-derived cytokines can be regarded as a reflection of $\mathrm{T}$ cell responses. For instance, a higher count of IFN- $\gamma$-producing cells than IL17-producing cells in the muscles of patients with DM/PM has been reported, and the ratio of IFN- $\gamma / \mathrm{IL}-17-$ producing cells is connected to the therapeutic results of high-dose immunoglobulin. Because IFN- $\gamma$ and IL-17 are key cytokines for Th1 and Th17 cells, a reasonable inference about biased $\mathrm{T}$ cell subgroups was concluded [69].

\subsection{Circulating $\mathrm{T}$ cells}

It remains unclear whether muscle-infiltrating lymphocytes are activated in situ or in the circulation. On the one hand, studies have demonstrated the presence of extranodal lymphoid microstructures in muscle biopsy samples from patients with juvenile DM [70]; in this situation, lymphocytes are able to activate and differentiate in local lesions. On the other hand, circulating T-cell repertoires in IIMs are also dramatically perturbed, persistent in the long term and myocytotoxic $[71,72]$. One typical example is the enrichment of highly pro-inflammatory and cytotoxic CD28null $\mathrm{T}$ cells found in the circulation of IIM patients [48, 49]. The similar nature of $\mathrm{T}$ cells in the two sites suggests their likely identical origin and underlines the particular clinical value of assessing these subsets in the peripheral blood.

\section{Tregs}

Although existence of Tregs in IIM muscle has been detected [30,73], more attention has been paid to their circulating compartment, and a decreased percentage of Tregs in the peripheral blood of IIM patients has been reported. Among studies to date, the suppressor function of Tregs was normal or impaired [74-76]. The possible explanation for reduced Tregs levels is inappropriate apoptosis in these cells. Combined therapies using glucocorticoids plus antimalarial or other immunosuppressants might additionally diminish Treg proportions through inhibition of cytokines essential for cell homeostasis [74]. In juvenile DM, the normal percentages of peripheral Tregs are increased after high corticosteroid treatment. Nonetheless, Tregs separated from the blood of patients with active disease display a compromised suppressive function towards effector $\mathrm{T}$ cells when compared with patients in clinical remission. Effects of the pro-inflammatory environment on Treg function and the resistance of effector $\mathrm{T}$ cells to Tregmediated suppression have been suggested as possible mechanisms [77].

\section{T-bet (T-box expressed in $T$ cells) ${ }^{+}$cells}

T-bet is one of two major T-box transcription factors essential for the differentiation of CTLs from naïve CD8+ $\mathrm{T}$ cells [78]. An increased frequency of CD8+ cells, including TEMs and TEMRAs, with high levels of T-bet expression in the peripheral blood of IBM patients has been observed. Although these CD8+T-bet+ cells overexpress the senescence marker CD57, a group of activated CD8+T-bet+ CD57null cells expressing lower levels of CD28, CD27 and CD127 as well as higher levels of CD38 and HLA-DR has been identified in IBM. In addition, CD8+T-bet+ cells are reported to be a favourable diagnostic biomarker. When the frequency of these cells is $>51.5 \%$, the sensitivity and specificity for distinguishing IBM patients from other myositis patients can reach $94.4 \%$ and $88.5 \%$, respectively [79].

\section{Skewing of $T$ cell subsets detected in the peripheral blood}

Subpopulations of $\mathrm{T}$ cells are mutually restrained to maintain the balance of the immune response, and a shift in $\mathrm{T}$ cells can have stimulatory effects on IIM pathogenesis. For example, DM patients have a unique T cell signature with increased CD4+ T cell and Th17 cell frequencies in the peripheral blood. Both DM and PM patients exhibit decreased circulating CD8+ central memory T-cells [80]. A significantly lower frequency of IL-4+ Th1/IFN- $\gamma+$ Th2 cells in the peripheral blood of active DM patients than in healthy controls has been reported, supporting the deflection towards Th2-mediated inflammatory processes [81]. Additionally, levels of Tfh cells, which are specialised to support B cell maturation in germinal centres, were markedly increased in an IMNM patient with HMGCR autoantibody positivity and subsequently declined after immunosuppressive therapy, with an improved clinical outcome [82]. The circulating memory compartment of $\mathrm{Tfh}$, which is defined as CXCR5+CD4+ $\mathrm{T}$ cells, is profoundly skewed towards Tfh 2 and Tfh17, as opposed to Tfh 1 cells, in juvenile DM patients, and such altered overall $\mathrm{Tfh}$ cell differentiation has been linked to disease activity and the frequency of 
blood plasmablasts [83]. The same discovery about Tfh cells was verified in DM/PM. In this study, elevated Th17 cells and decreased Tregs within the context of lymphopenia were also detected [84].

\section{Transcriptomics and TCR-mediated signalling pathways in IIM T cells}

Whole-transcriptome analysis of peripheral blood CD4+ and $\mathrm{CD} 8+\mathrm{T}$ cells in $\mathrm{DM} / \mathrm{PM}$ patients has revealed different profiles. Compared with DM, ANKRD55 and S100B are highly expressed in CD4+ T cells in PM. And a total of 176 genes were found to be differentially expressed (44 genes up-regulated and 132 genes downregulated) in CD8+ T cells in PM. Functional analysis suggested that these altered genes are involved in lymphocyte migration and regulation of T-cell differentiation [85]. In studies of the TCR-mediated intracellular signalling pathway, expression of signal transducer and activator of transcription (STAT), forkhead box transcription factor (FoxP3) and TCRinduced phosphorylated zeta-chain-associated protein kinase 70 (pZAP70) in CD4+ T cells of DM patients was found to be suppressed. Furthermore, STAT and pZAP70 expression in CD8+ T cells is elevated in PM. Increases in suppressor of cytokine signalling-3 (SOCS3) and decreases in interleukin 6 signal transducer (IL6ST) in CD4+ T cells of both DM and PM patients have also been reported [86]. In summary, different gene expression and related pathways were found in T cells of DM and PM, suggesting different functions during DM/PM pathogenesis.

\section{B cells in IIMs}

The development of B cells begins in the bone marrow, where a diverse repertoire of B cell receptors (BCRs) can be generated through multiple rearrangements of immunoglobulin genes [87]. After eliminating autoreactivity, B cells gain tolerance to self-antigens and migrate to the periphery [88]. The final stages of B cell maturation occur in the follicles of the spleen and require the TNF family member B cell activating factor (BAFF) as well as B cell receptor signals [89]. Similarly, naïve B cells undergo no antigenic stimulation; they usually need to interact with Th cells for activation and ultimately differentiate into antibody-secreting plasma cells and memory B cells under antigen stimulation [90].

Activation of B cells in IIMs can be deduced from the frequent records of myositis-specific (MSAs) or myositis-associated (MAAs) autoantibodies, with apparent associations with clinical phenotypes and potential pathogenicity of self-antigens in target tissues [91-93]. BAFF is also believed to be crucial for the production of autoantibodies [89]. Increased levels of serum BAFF in subsets of IIMs have been reported, especially for patients positive for anti-Jo-1 antibodies. Moreover, BAFF levels correlate significantly with the titer of anti-Jo-1 antibodies and decline with the administration of glucocorticoids[94, 95]. Expression of $\mathrm{BAFF}$ is also markedly increased in muscle fibres in the perifascicular area of DM patients. Correspondingly, the receptor for BAFF is strongly expressed by infiltrated inflammatory cells $[96,97]$.

\subsection{Muscle-infiltrating B cells}

Despite not being as common as $\mathrm{T}$ cells, muscleinfiltrating B cells in muscle biopsy samples from patients with IIMs are clonally diversified and display deviant immunoglobulin $\mathrm{V}_{\mathrm{H}}$ gene repertoires, indicating chronic local antigen-driven humoral responses [98, 99]. Interestingly, the quantity of B cells and the formation of ectopic follicle-like structures in the muscles of DM patients have been associated with the level of cytokines or chemokines involved in lymphoid neogenesis as well as type I interferon-related immunity [100]. However, concentrated collections of germinal-centre-like B cell follicles are absent in the muscles of patients with myositis. This finding argues against their necessity for antigen-stimulated clonal maturation of $\mathrm{B}$ cells [101]. Plasma cells are also components of inflammatory infiltrates in muscle biopsy specimens of IIM patients. In fact, the proportion of plasma cells (defined as CD138 positive) is even higher in IIM muscle than that of B cells [102].

\subsection{Circulating B cells}

Circulating $\mathrm{B}$ cells also undergo great changes in the disease process of IIMs. Naïve B cells and memory B cells are more and less abundant, respectively, in patients with DM/PM and anti-JO-1 antisynthetase syndrome (a special type of IIM characterised by antisynthetase autoantibodies and frequent interstitial lung disease) [80, 103 , 104]. In pre-treatment juvenile DM, highly proliferative immature transitional $\mathrm{B}$ cells undergo significant expansion, and their frequency is strongly associated with the type 1 interferon signature. Given that the proportion or absolute number of immature transitional B cells correlates positively with disease activity, these cells are presumed to have a role in the development of juvenile DM [105]. Despite the fact that the percentage of transitional B cells in DM does not differ from that in healthy controls, levels of these cells are obviously decreased after treatment, which is accompanied by an increase in memory B cells [103]. In another study, a distinctly elevated proportion of RP105- 
negative B cells in DM compared with PM and normal controls was discovered. The loss of surface RP105 has previously been shown to act as a sign of B cell activation [106]. Similar to Tregs, regulatory B cells (Bregs) have potent immunosuppressive activity. Furthermore, Bregs are dramatically reduced in DM patients and may have a relationship with myositis-specific autoantibodies, pulmonary interstitial fibrosis and global disease scores [107].

\section{Other immune cells in IIMs}

\section{NK cells}

Scant but sufficient evidence indicates altered quantities and functions of NK cells in patients with IIMs. In antisynthetase syndrome, NK cells exhibit an intense and diffuse distribution in fibrotic areas of the lungs, despite their rarity in muscle specimens. Although the quantity of NK cells in the circulation of patients with active disease is unaffected, these cells acquire an enhanced capacity to produce granzymes and IFN- $\gamma[108,109]$. In juvenile DM, NK cells have been found to be enriched in the affected muscles of untreated patients, especially those with a short disease duration [110]. Conversely, the frequency of circulating NK cells is reduced and displays a trend towards normalisation after the cessation of active disease. These NK cells in patients with juvenile DM are more highly activated and proliferative than are the NK cells of healthy controls [111].

\section{Macrophages}

Entry of macrophages into muscle tissue has been verified in all types of IIMs, including IMNM, with a main distribution around the endomysium and perimysium [91, 112-114]. Proteomic profiling of muscle biopsies derived from sIBM patients has also revealed the macrophage scavenger molecule CD163 as a highly and relevantly expressed protein, suggesting significant involvement of macrophages in muscle pathology [115]. Interestingly, a large proportion of diffuse endomysial macrophage infiltrates has more often been found in juvenile IIMs with MSAs towards nuclear matrix protein 2 (NXP2) and transcriptional intermediary factor $1 \gamma$ (TIF1 $\gamma$ ) [116], indicating a correlation of serological subtype with histological features. Upon activation, macrophages shed CD163 molecules from their membrane and release them into the peripheral blood [117], and higher levels of soluble CD163 in the circulation have been observed in patients with $\mathrm{PM} / \mathrm{DM}$ complicated with interstitial lung disease (ILD) than in those without ILD and healthy volunteers [118]. That is, activation of macrophages may be important in PM/DM-related ILD.

\section{Dendritic cells}

There are two main types of dendritic cells (DCs) mediating distinct biological processes. Myeloid DCs are potent antigen-presenting cells of adaptive immunity, and plasmacytoid DCs play a vital role in innate immunity, specifically during viral infection [32]. Although plasmacytoid DCs can also be present in the biopsies of normal muscle, their absolute count is very small. Both myeloid DCs and plasmacytoid DCs have been found in the muscle tissues of DM/PM/IBM patients, with a predominance of plasmacytoid DCs in DM and myeloid DCs in PM/IBM (plasmacytoid DCs were defined as BDCA-2+ or CD4+CD83+CD123+ and myeloid DCs as BDCA-1+ after excluding CD19+ B cells) [119-121]. Because plasmacytoid DCs are the major source of type I interferons, it makes sense why DM exhibits a remarkable type I interferon signature [122]. The distribution of DCs (immature DCs were defined as CD1a+ and mature DCs as CD83+DC-LAMP+) in inflamed muscles resembles a pattern of infiltrating $\mathrm{T}$ cells with a perivascular location in DM and an endomysial location in PM [27]. Their accumulation in IIM muscle tissues can contribute to an ongoing immune-mediated reaction and further muscle damage.

\section{Mesenchymal stem cells}

Mesenchymal stem cells (MSCs) have gained much attention as a safe and beneficial therapy against a wide array of chronic inflammatory diseases [123, 124]. Transplantation of allogeneic MSCs showed efficacy in a small-scale pilot study including 10 patients with drugresistant PM or DM. These patients exhibited decreased serum creatine kinase and improved muscle strength [125]. The underlying therapeutic mechanisms of MSCs in IIMs are unknown, and their regenerative and multipotential properties as well as potent immunosuppressive activities may be plausible; further exploration is needed [126, 127].

\section{Low-density granulocytes}

Low-density granulocytes (LDGs) were first identified in systemic lupus erythematosus and later in many other autoimmune, cancer and infectious diseases [15]. These cells have either pro-inflammatory or suppressive properties, and the former is regarded as the main contributor to their pathogenicity via excessive secretion of IFN and TNF- $\alpha$ [128]. Besides, LDGs can efficiently form neutrophil extracellular traps (NETs) [129], which contain abundant endocellular materials and are able to activate the immune system as autoantigens under certain conditions [130]. The percentage of LDGs in the 
peripheral blood mononuclear cells of DM patients was abnormally increased. Moreover, patients with DM complicated by ILD have higher levels of LDGs than do those without ILD. LDGs may accelerate the onset of ILD in DM patients by abnormal NET regulation [131].

Table 1. Immune cells in IIMs.

\begin{tabular}{|c|c|c|c|c|}
\hline Immune cells & Change & Characters & $\begin{array}{l}\text { IIM subtype and } \\
\text { classification criteria }\end{array}$ & Ref. \\
\hline \multicolumn{5}{|l|}{ Muscle-infiltrating T cells } \\
\hline CD28-T cells & increased & more cytotoxic, drug resistance & $\mathrm{DM}^{1}, \mathrm{PM}^{1}, \mathrm{IBM}^{4}$ & {$[48-50,52]$} \\
\hline $\begin{array}{l}\text { highly differentiated cytotoxic } \mathrm{T} \\
\text { cells }\end{array}$ & increased & $\begin{array}{l}\text { co-express cytotoxic genes and } \\
\text { KLRG1 }\end{array}$ & $\mathrm{IBM}^{5}$ & {$[56]$} \\
\hline $\mathrm{CD} 45 \mathrm{RO}+\mathrm{T}$ cells & increased & -- & $\mathrm{DM}^{1}, \mathrm{PM}^{1}, \mathrm{IBM}^{7}$ & {$[58]$} \\
\hline $\mathrm{CD} 8+\mathrm{NKG} 2 \mathrm{D}^{\text {high }} \mathrm{T}$ cells & increased & target cells independent of TCR & $\mathrm{PM}^{2}$ & {$[61]$} \\
\hline $\mathrm{CD} 8+\mathrm{ICOS}+\mathrm{T}$ cells & increased & enhanced perforin expression & $\mathrm{IBM}^{3}$ & {$[64]$} \\
\hline CCR7+ T cells & increased & -- & $\mathrm{PM}^{7}, \mathrm{IBM}^{7}$ & {$[66,67]$} \\
\hline $\begin{array}{l}\text { IL-4-producing CXCR4+ Th2 T } \\
\text { cells }\end{array}$ & increased & $\begin{array}{l}\text { correlated with lower level of CK } \\
\text { and LDH }\end{array}$ & $\mathrm{DM}^{1}, \mathrm{PM}^{1}$ & {$[68]$} \\
\hline IFN $\gamma+$ Th1/IL17+Th17 ratio & increased & $\begin{array}{l}\text { response poorly to high-dose } \\
\text { immunoglobulins }\end{array}$ & $\mathrm{DM}^{1}, \mathrm{PM}^{1}$ & [69] \\
\hline \multicolumn{5}{|l|}{ Circulating T cells } \\
\hline \multirow[t]{2}{*}{ Tregs } & decreased & normal function & $\mathrm{DM}^{1,2}, \mathrm{PM}^{1}, \mathrm{IBM}^{4}$ & [74-76] \\
\hline & normal & $\begin{array}{l}\text { compromised suppressive function } \\
\text { towards effector T cells }\end{array}$ & juvenile $\mathrm{DM}^{1}$ & {$[77]$} \\
\hline CD8+T-bet+ cells & increased & $\begin{array}{l}\text { favourable value as diagnostic } \\
\text { biomarker }\end{array}$ & $\mathrm{IBM}^{5}$ & [79] \\
\hline CD4+ T cells & $\begin{array}{l}\text { increased or } \\
\text { normal }\end{array}$ & $\begin{array}{l}\text { different TCR-mediated } \\
\text { characteristic signalling pathway }\end{array}$ & $\mathrm{DM}^{1}, \mathrm{PM}^{1}$, juvenile $\mathrm{DM}^{1}$ & {$[80,86]$} \\
\hline CD8+ central memory T-cells & decreased & -- & $\mathrm{DM}^{1}, \mathrm{PM}^{1}$, juvenile $\mathrm{DM}^{1}$ & {$[80]$} \\
\hline IL4+ Th1/IFN $\gamma+$ Th2 ratio & decreased & -- & $\mathrm{DM}^{1}$ & {$[81]$} \\
\hline $\begin{array}{l}\mathrm{CXCR} 5+\mathrm{CD} 4+\mathrm{Tfh} 2 \& \mathrm{Tfh} 17 / \mathrm{Tfh} 1 \\
\text { ratio }\end{array}$ & increased & $\begin{array}{l}\text { linked with disease activity and } \\
\text { frequency of blood plasmablasts }\end{array}$ & $\mathrm{DM}^{1}, \mathrm{PM}^{1}$, juvenile $\mathrm{DM}^{1}$ & {$[83,84]$} \\
\hline Th17 cells & increased & -- & $\mathrm{DM}^{1}, \mathrm{PM}^{1}$ & {$[80,84]$} \\
\hline Muscle-infiltrating B cells & increased & $\begin{array}{l}\text { clonally diversified and forming } \\
\text { ectopic follicle-like structures }\end{array}$ & $\mathrm{DM}^{2,7}, \mathrm{PM}^{2,7}, \mathrm{IBM}^{4}$ & [98-101] \\
\hline CD138+ plasma cells & increased & -- & $\mathrm{PM}^{2}, \mathrm{IBM}^{4}$ & {$[102]$} \\
\hline \multicolumn{5}{|l|}{ Circulating B cells } \\
\hline naïve $B$ cell/memory $B$ cell ratio & increased & -- & $\mathrm{DM}^{1}$, antisynthetase syndrome ${ }^{7}$ & {$[103,104]$} \\
\hline \multirow[t]{2}{*}{ transitional B cells } & increased & $\begin{array}{l}\text { associated with type } 1 \text { IFN } \\
\text { signature }\end{array}$ & juvenile $\mathrm{DM}^{1}$ & {$[105]$} \\
\hline & $\begin{array}{l}\text { normal but } \\
\text { decreased } \\
\text { after } \\
\text { treatment }\end{array}$ & -- & $\mathrm{DM}^{1}$ & {$[103]$} \\
\hline RP105 negative B cells & increased & sign of activation & $\mathrm{DM}^{1}$ & [106] \\
\hline Bregs & decreased & $\begin{array}{l}\text { related to MSAs, ILD and global } \\
\text { disease scores }\end{array}$ & $\mathrm{DM}^{1}$ & {$[107]$} \\
\hline Muscle-infiltrating NK cells & increased & -- & juvenile $\mathrm{DM}^{7}$ & [110] \\
\hline \multirow[t]{2}{*}{ Circulating NK cells } & normal & $\begin{array}{l}\text { enhanced capacity to produce } \\
\text { granzymes and IFN- } \gamma\end{array}$ & antisynthetase syndrome $^{7}$ & {$[108,109]$} \\
\hline & decreased & $\begin{array}{l}\text { normalize after cessation of active } \\
\text { disease }\end{array}$ & juvenile $\mathrm{DM}^{1}$ & [110] \\
\hline Muscle-infiltrating macrophages & increased & correlated with MSAs & $\begin{array}{l}\mathrm{DM}^{3,7}, \mathrm{PM}^{3,7}, \mathrm{IBM}^{6}, \mathrm{IMNM}^{7}, \\
\text { juvenile } \mathrm{DM}^{1} / \mathrm{PM}^{1}\end{array}$ & $\begin{array}{l}{[91,112-114,} \\
116]\end{array}$ \\
\hline Muscle-infiltrating DCs & increased & -- & $\mathrm{DM}^{1,2} / \mathrm{PM}^{1,2} / \mathrm{IBM}^{4}$ & {$[27,119-121]$} \\
\hline MSCs & -- & show efficient therapeutic effects & drug-resistant $\mathrm{DM}^{1} / \mathrm{PM}^{1}$ & [125] \\
\hline LDGs in PBMCs & increased & associated with ILD & $\mathrm{DM}^{1}$ & [131] \\
\hline \multicolumn{5}{|c|}{$\begin{array}{l}\text { 1, Bohan/Peter criteria; 2, criteria of the 119th ENMC international workshop; 3, Dalakas' criteria; 4, Griggs' criteria; 5, Lloyd's criteria; 6, criteria } \\
\text { of the 188th ENMC international workshop; 7, criteria not mentioned } \\
\text { Th, T helper; IFN, Interferon; Tfh, T follicular helper; Tregs, regulatory T cells; T-bet, T-box expressed in T cells; Bregs, regulatory B cells; DCs, } \\
\text { dendritic cells; MSCs, mesenchymal stem cells; LDGs, low-density granulocytes; PBMC, peripheral blood mononuclear cell; KLRG1, killer cell } \\
\text { lectin-like receptor G1; TCR, T cell receptor; CK, creatinine kinase; LDH, lactate dehydrogenase; MSAs, myositis-specific antibodies; ILD, } \\
\text { interstitial lung disease; DM, dermatomyositis; PM, polymyositis; IBM, inclusion body myositis; IMNM, immune-mediated necrotising myopathy }\end{array}$} \\
\hline
\end{tabular}




\section{Therapies targeting immune cells or related pathways}

Because immune cells are dominant components in the pathogenesis of IIMs, a number of pharmacological treatments targeting them, and related pathways have emerged. These therapies have provided IIM patients more choices and significant improvement in prognosis.

\section{Conventional immunosuppressants}

Mycophenolate mofetil (MMF) and calcineurin inhibitors are two types of conventional immunosuppressants used in IIM patients. MMF can impair the proliferation of $\mathrm{T}$ cells and B cells. In an open study enrolling seven patients with either refractory DM or PM, MMF plus intravenous immunoglobulin (IVIG) led to complete remission in all cases [132]. The effectiveness of MMF alone or in combination has also been verified in several small case series [133-135]. Calcineurin inhibitors such as ciclosporin and tacrolimus can inhibit $\mathrm{T}$ cell activation and are commonly used in IIMs. Cyclosporine combined with glucocorticoids improved the findings of pulmonary function tests (PFTs) and chest high-resolution computed tomography (HRCTs) in 14 DM patients with acute/subacute ILD within 12 days from diagnosis [136]. Tacrolimus also showed favorable effects in treating 13 patients with antisynthetase syndrome (12 with anti-Jo-1 and 1 with anti-PL-12 autoantibodies), as indicated by better muscle strength, serum creatine CK levels, and PFT parameters [137]. In two more studies, one including 8 patients with myositis ( 6 with anti-Jo-1 and 2 with antiSRP autoantibodies) and another including 31 patients with myositis (16 PM and $15 \mathrm{DM}$ patients), tacrolimus improved both the muscle strength and serum CK levels [138, 139].

\section{Biologic and targeted synthetic disease-modifying anti- rheumatic drugs}

Biological agents can selectively exhaust target immune cells or cytokines [140]. As a fusion protein composed of the Fc region of human IgG1 and the extracellular domain of cytotoxic T-lymphocyte-associated protein 4 (CTLA4), abatacept inhibits the second signal for $\mathrm{T}$ cell activation by CD80 or CD86. In a randomised clinical trial, $42 \%$ of patients with refractory DM/PM achieved the preliminary definition of improvement coupled with increased Treg levels, as based on repeated muscle biopsies, after aggressive treatment of abatacept for 6 months [141]. Rituximab is able to rapidly deplete B cells by binding to the surface molecule CD20 and is promising for alleviating IIMs, even those with intractable phenotypes [142-146]. One review including 458 IIM patients who were nonresponsive to standard therapies found that $78.3 \%$ experienced improvement in at least one manifestation after treatment with rituximab. Among the cases, some were complicated with severe/refractory ILD [147]. Tocilizumab is an interleukin 6 (IL-6)-receptor antagonist with efficacy in treating IIMs as concluded in a few case reports [148, 149]. IL-6 can induce T cell differentiation and initially trigger BAFF [150]. However, more valid evidence from randomised, multicenter, double-blind trials is needed to confirm the curative effect of tocilizumab. Sifalimumab, an anti-IFN $\alpha$ monoclonal antibody, can interfere with the production of type I IFNinducible proteins involved in the innate immune system. Treatment with sifalimumab in DM and PM patients resulted in suppression of the IFN signature in the blood and muscle tissue accompanied by clinical improvement [151]. The Janus kinase (JAK)- STAT signalling pathway is crucial in the IFN-mediated activation of cytokine receptors, and an inhibitor of JAK-1/3, tofacitinib, exhibited satisfactory effects on refractory DM as well as associated ILD [152-156].

\section{Conclusion}

Accumulating advances in pathogenesis elucidation have prompted a better understanding of IIMs. Immune cells in the peripheral blood and inflamed tissues of IIM patients show significant numerical or phenotypic changes leading to pathogenetic immune imbalance. The encouraging therapeutic effects of biologic agents targeting immune cells and related pathways also emphasise a key role for the immune response in the pathogenesis of IIMs. To our knowledge, this is the first review that summarises the participation of immune cells in IIMs and discusses potential targets for treatment. Because the specific approaches by which immune cells influence IIMs are still far from completely understood, elaborate mechanistic studies should be performed to facilitate more precise medical interventions.

\section{Conflicts of interest}

The authors declare no conflicts of interest.

\section{Acknowledgements}

This work was supported by grants from Hunan Provincial Natural Science Foundation (2018JJ3823) and National Natural Science Foundation of China (81671621).

\section{References}

[1] Amici DR, Pinal-Fernandez I, Pagkatipunan R, Mears 
A, de Lorenzo R, Tiniakou E et al. (2019). Muscle endurance deficits in myositis patients despite normal manual muscle testing scores. Muscle Nerve,59:70-5.

[2] Alexanderson H, Regardt M, Ottosson C, Alemo Munters L, Dastmalchi M, Dani L et al. (2018). Muscle Strength and Muscle Endurance During the First Year of Treatment of Polymyositis and Dermatomyositis: A Prospective Study. J Rheumatol,45:538-46.

[3] Alemo Munters L, Dastmalchi M, Katz A, Esbjornsson M, Loell I, Hanna B et al. (2013). Improved exercise performance and increased aerobic capacity after endurance training of patients with stable polymyositis and dermatomyositis. Arthritis Res Ther,15:R83.

[4] Lundberg IE, de Visser M, Werth VP (2018). Classification of myositis. Nat Rev Rheumatol,14:269-78.

[5] Gao S, Luo H, Zhang H, Zuo X, Wang L, Zhu H (2017). Using multi-omics methods to understand dermatomyositis/polymyositis. Autoimmun Rev, 16:1044-8.

[6] Xiao Y, Zhu H, Li L, Gao S, Liu D, Dai B et al. (2019). Global analysis of protein expression in muscle tissues of dermatomyositis/polymyosisits patients demonstrated an association between dysferlin and human leucocyte antigen A. Rheumatology (Oxford).

[7] Zong M, Lundberg IE (2011). Pathogenesis, classification and treatment of inflammatory myopathies. Nat Rev Rheumatol,7:297-306.

[8] Korotkova M, Helmers SB, Loell I, Alexanderson H, Grundtman C, Dorph C et al. (2008). Effects of immunosuppressive treatment on microsomal prostaglandin E synthase 1 and cyclooxygenases expression in muscle tissue of patients with polymyositis or dermatomyositis. Ann Rheum Dis, 67:1596-602.

[9] Miller FW, Lamb JA, Schmidt J, Nagaraju K (2018). Risk factors and disease mechanisms in myositis. Nat Rev Rheumatol,14:255-68.

[10] Huang K, Li QX, Bi FF, Duan HQ, Mastaglia F, Luo YB et al. (2018). Comparative immunoprofiling of polymyositis and dermatomyositis muscles. Int J Clin Exp Pathol,11:3984-93.

[11] Netea MG, Schlitzer A, Placek K, Joosten LAB, Schultze JL (2019). Innate and Adaptive Immune Memory: an Evolutionary Continuum in the Host's Response to Pathogens. Cell Host Microbe,25:13-26.

[12] Mace EM, Orange JS (2019). Emerging insights into human health and NK cell biology from the study of NK cell deficiencies. Immunol Rev,287:202-25.

[13] Jenkins SJ, Hume DA (2014). Homeostasis in the mononuclear phagocyte system. Trends Immunol,35:358-67.

[14] Alunno A, Bistoni O, Montanucci P, Basta G, Calafiore R, Gerli R (2018). Umbilical cord mesenchymal stem cells for the treatment of autoimmune diseases: beware of cell-to-cell contact. Ann Rheum Dis, 77:e14.

[15] Rahman S, Sagar D, Hanna RN, Lightfoot YL, Mistry
P, Smith CK et al. (2019). Low-density granulocytes activate $\mathrm{T}$ cells and demonstrate a non-suppressive role in systemic lupus erythematosus. Ann Rheum Dis, 78:957-66.

[16] Springer TA (1994). Traffic signals for lymphocyte recirculation and leukocyte emigration: the multistep paradigm. Cell,76:301-14.

[17] Jenkins MK, Chu HH, McLachlan JB, Moon JJ (2010). On the composition of the preimmune repertoire of $\mathrm{T}$ cells specific for Peptide-major histocompatibility complex ligands. Annu Rev Immunol,28:275-94.

[18] Harty JT, Badovinac VP (2008). Shaping and reshaping CD8+ T-cell memory. Nat Rev Immunol,8:107-19.

[19] Zhu J, Yamane H, Paul WE (2010). Differentiation of effector CD4 $\mathrm{T}$ cell populations (*). Annu Rev Immunol,28:445-89.

[20] Malmstrom V, Venalis P, Albrecht I (2012). T cells in myositis. Arthritis Res Ther, 14:230.

[21] Emslie-Smith AM, Arahata K, Engel AG (1989). Major histocompatibility complex class I antigen expression, immunolocalization of interferon subtypes, and $\mathrm{T}$ cell-mediated cytotoxicity in myopathies. Hum Pathol,20:224-31.

[22] Pedrol E, Grau JM, Casademont J, Cid MC, Masanes F, Fernandez-Sola J et al. (1995). Idiopathic inflammatory myopathies. Immunohistochemical analysis of the major histocompatibility complex antigen expression, inflammatory infiltrate phenotype and activation cell markers. Clin Neuropathol,14:17984.

[23] Nishio J, Suzuki M, Miyasaka N, Kohsaka H (2001). Clonal biases of peripheral CD8 $\mathrm{T}$ cell repertoire directly reflect local inflammation in polymyositis. $\mathrm{J}$ Immunol, 167:4051-8.

[24] Mizuno K, Yachie A, Nagaoki S, Wada H, Okada K, Kawachi $\mathrm{M}$ et al. (2004). Oligoclonal expansion of circulating and tissue-infiltrating $\mathrm{CD} 8+\mathrm{T}$ cells with killer/effector phenotypes in juvenile dermatomyositis syndrome. Clin Exp Immunol,137:187-94.

[25] Dimitri D, Benveniste O, Dubourg O, Maisonobe T, Eymard B, Amoura Z et al. (2006). Shared blood and muscle CD8+ T-cell expansions in inclusion body myositis. Brain, 129:986-95.

[26] Benveniste O, Cherin P, Maisonobe T, Merat R, Chosidow O, Mouthon L et al. (2001). Severe perturbations of the blood $\mathrm{T}$ cell repertoire in polymyositis, but not dermatomyositis patients. J Immunol,167:3521-9.

[27] Page G, Chevrel G, Miossec P (2004). Anatomic localization of immature and mature dendritic cell subsets in dermatomyositis and polymyositis: Interaction with chemokines and Th1 cytokineproducing cells. Arthritis Rheum,50:199-208.

[28] Chevrel G, Page G, Granet C, Streichenberger N, Varennes A, Miossec P (2003). Interleukin-17 increases the effects of IL-1 beta on muscle cells: arguments for the role of T cells in the pathogenesis of myositis. J Neuroimmunol,137:125-33.

[29] Venalis P, Lundberg IE (2014). Immune mechanisms 
in polymyositis and dermatomyositis and potential targets for therapy. Rheumatology (Oxford),53:397405.

[30] Waschbisch A, Schwab N, Ruck T, Stenner MP, Wiendl $H$ (2010). FOXP3 $+T$ regulatory cells in idiopathic inflammatory myopathies. $\mathrm{J}$ Neuroimmunol,225:137-42.

[31] Delemarre EM, van den Broek T, Mijnheer G, Meerding J, Wehrens EJ, Olek S et al. (2016). Autologous stem cell transplantation aids autoimmune patients by functional renewal and TCR diversification of regulatory $\mathrm{T}$ cells. Blood,127:91101.

[32] Tournadre A, Miossec P (2009). Chemokines and dendritic cells in inflammatory myopathies. Ann Rheum Dis, 68:300-4.

[33] Dalakas MC, Hohlfeld R (2003). Polymyositis and dermatomyositis. Lancet,362:971-82.

[34] Gao S, Zuo X, Liu D, Xiao Y, Zhu H, Zhang H et al. (2018). The roles of neutrophil serine proteinases in idiopathic inflammatory myopathies. Arthritis Res Ther,20:134.

[35] Gao S, Zhu H, Yang H, Zhang H, Li Q, Luo H (2017). The role and mechanism of cathepsin $G$ in dermatomyositis. Biomed Pharmacother,94:697-704.

[36] Acuto O, Michel F (2003). CD28-mediated costimulation: a quantitative support for TCR signalling. Nat Rev Immunol,3:939-51.

[37] Acuto O, Mise-Omata S, Mangino G, Michel F (2003). Molecular modifiers of $\mathrm{T}$ cell antigen receptor triggering threshold: the mechanism of CD28 costimulatory receptor. Immunol Rev,192:21-31.

[38] Mou D, Espinosa J, Lo DJ, Kirk AD (2014). CD28 negative $\mathrm{T}$ cells: is their loss our gain? Am $\mathrm{J}$ Transplant, 14:2460-6.

[39] Appay V, Dunbar PR, Callan M, Klenerman P, Gillespie GM, Papagno L et al. (2002). Memory CD8+ $\mathrm{T}$ cells vary in differentiation phenotype in different persistent virus infections. Nat Med,8:379-85.

[40] Bryl E, Vallejo AN, Weyand CM, Goronzy JJ (2001). Down-regulation of CD28 expression by TNF-alpha. J Immunol, 167:3231-8.

[41] Betjes MG (2016). Clinical consequences of circulating CD28-negative $\mathrm{T}$ cells for solid organ transplantation. Transpl Int,29:274-84.

[42] Fasth AE, Bjorkstrom NK, Anthoni M, Malmberg KJ, Malmstrom V (2010). Activating NK-cell receptors co-stimulate CD4(+)CD28(-) T cells in patients with rheumatoid arthritis. Eur J Immunol,40:378-87.

[43] Namekawa T, Wagner UG, Goronzy JJ, Weyand CM (1998). Functional subsets of CD4 T cells in rheumatoid synovitis. Arthritis Rheum,41:2108-16.

[44] Strioga M, Pasukoniene V, Characiejus D (2011). CD8+ CD28- and CD8+ CD57+ T cells and their role in health and disease. Immunology,134:17-32.

[45] Posnett DN, Edinger JW, Manavalan JS, Irwin C, Marodon G (1999). Differentiation of human CD8 T cells: implications for in vivo persistence of CD8+ CD28- cytotoxic effector clones. Int Immunol,11:22941.
[46]
Schmidt D, Martens PB, Weyand CM, Goronzy JJ (1996). The repertoire of CD4+ CD28- T cells in rheumatoid arthritis. Mol Med,2:608-18.

Sun Z, Zhong W, Lu X, Shi B, Zhu Y, Chen L et al. (2008). Association of Graves' disease and prevalence of circulating IFN-gamma-producing CD28(-) T cells. J Clin Immunol,28:464-72.

Fasth AE, Dastmalchi M, Rahbar A, Salomonsson S, Pandya JM, Lindroos E et al. (2009). T cell infiltrates in the muscles of patients with dermatomyositis and polymyositis are dominated by CD28null T cells. J Immunol,183:4792-9.

Pandya JM, Fasth AE, Zong M, Arnardottir S, Dani L, Lindroos E et al. (2010). Expanded T cell receptor Vbeta-restricted $\mathrm{T}$ cells from patients with sporadic inclusion body myositis are proinflammatory and cytotoxic CD28null T cells. Arthritis Rheum,62:345766.

Pandya JM, Venalis P, Al-Khalili L, Shahadat Hossain M, Stache V, Lundberg IE et al. (2016). CD4+ and CD8+ CD28(null) $\mathrm{T}$ Cells Are Cytotoxic to Autologous Muscle Cells in Patients With Polymyositis. Arthritis Rheumatol,68:2016-26.

Nakajima T, Schulte S, Warrington KJ, Kopecky SL, Frye RL, Goronzy JJ et al. (2002). T-cell-mediated lysis of endothelial cells in acute coronary syndromes. Circulation, 105:570-5.

Pandya JM, Loell I, Hossain MS, Zong M, Alexanderson H, Raghavan S et al. (2016). Effects of conventional immunosuppressive treatment on CD244+ (CD28null) and FOXP3 $+\mathrm{T}$ cells in the inflamed muscle of patients with polymyositis and dermatomyositis. Arthritis Res Ther,18:80.

Schirmer M, Vallejo AN, Weyand CM, Goronzy JJ (1998). Resistance to apoptosis and elevated expression of Bcl-2 in clonally expanded CD4+CD28$\mathrm{T}$ cells from rheumatoid arthritis patients. $\mathrm{J}$ Immunol, 161:1018-25.

Kovalcsik E, Antunes RF, Baruah P, Kaski JC, Dumitriu IE (2015). Proteasome-mediated reduction in proapoptotic molecule Bim renders CD4(+)CD28null T cells resistant to apoptosis in acute coronary syndrome. Circulation, 131:709-20.

Benveniste O, Guiguet M, Freebody J, Dubourg O, Squier W, Maisonobe $\mathrm{T}$ et al. (2011). Long-term observational study of sporadic inclusion body myositis. Brain,134:3176-84.

Greenberg SA, Pinkus JL, Kong SW, Baecher-Allan C, Amato AA, Dorfman DM (2019). Highly differentiated cytotoxic $\mathrm{T}$ cells in inclusion body myositis. Brain,142:2590-604.

Mason D (1992). Subsets of CD4+ T cells defined by their expression of different isoforms of the leucocytecommon antigen, CD45. Biochem Soc Trans,20:18890 .

De Bleecker JL, Engel AG (1995). Immunocytochemical study of CD45 T cell isoforms in inflammatory myopathies. Am J Pathol,146:117887.

Verneris MR, Karimi M, Baker J, Jayaswal A, Negrin 
RS (2004). Role of NKG2D signaling in the cytotoxicity of activated and expanded CD8+ T cells. Blood, 103:3065-72.

[60] Roberts AI, Lee L, Schwarz E, Groh V, Spies T, Ebert EC et al. (2001). NKG2D receptors induced by IL-15 costimulate CD28-negative effector CTL in the tissue microenvironment. J Immunol,167:5527-30.

[61] Ruck T, Bittner S, Afzali AM, Gobel K, Glumm S, Kraft $\mathrm{P}$ et al. (2015). The NKG2D-IL-15 signaling pathway contributes to T-cell mediated pathology in inflammatory myopathies. Oncotarget,6:43230-43.

[62] Sharpe AH, Freeman GJ (2002). The B7-CD28 superfamily. Nat Rev Immunol,2:116-26.

[63] Carreno BM, Collins M (2002). The B7 family of ligands and its receptors: new pathways for costimulation and inhibition of immune responses. Annu Rev Immunol,20:29-53.

[64] Schmidt J, Rakocevic G, Raju R, Dalakas MC (2004). Upregulated inducible co-stimulator (ICOS) and ICOS-ligand in inclusion body myositis muscle: significance for $\mathrm{CD} 8+\mathrm{T}$ cell cytotoxicity. Brain, 127:1182-90.

[65] Armengol MP, Cardoso-Schmidt CB, Fernandez M, Ferrer X, Pujol-Borrell R, Juan M (2003). Chemokines determine local lymphoneogenesis and a reduction of circulating $\mathrm{CXCR} 4+\mathrm{T}$ and $\mathrm{CCR} 7 \mathrm{~B}$ and $\mathrm{T}$ lymphocytes in thyroid autoimmune diseases. $\mathrm{J}$ Immunol,170:6320-8.

[66] Tateyama M, Fujihara K, Misu T, Itoyama Y (2009). CCR7+ myeloid dendritic cells together with CCR7+ $\mathrm{T}$ cells and CCR7+ macrophages invade CCL19+ nonnecrotic muscle fibers in inclusion body myositis. J Neurol Sci,279:47-52.

[67] Tateyama M, Fujihara K, Misu T, Feng J, Onodera Y, Itoyama Y (2006). Expression of CCR7 and its ligands CCL19/CCL21 in muscles of polymyositis. J Neurol Sci,249:158-65.

[68] Fujiyama T, Ito T, Ogawa N, Suda T, Tokura Y, Hashizume $H$ (2014). Preferential infiltration of interleukin-4-producing CXCR4+ $\mathrm{T}$ cells in the lesional muscle but not skin of patients with dermatomyositis. Clin Exp Immunol,177:110-20.

[69] Tournadre A, Porcherot M, Cherin P, Marie I, Hachulla E, Miossec P (2009). Th1 and Th17 balance in inflammatory myopathies: interaction with dendritic cells and possible link with response to high-dose immunoglobulins. Cytokine,46:297-301.

[70] Lopez De Padilla CM, Vallejo AN, Lacomis D, McNallan K, Reed AM (2009). Extranodal lymphoid microstructures in inflamed muscle and disease severity of new-onset juvenile dermatomyositis. Arthritis Rheum,60:1160-72.

[71] Benveniste O, Herson S, Salomon B, Dimitri D, Trebeden-Negre H, Jean L et al. (2004). Long-term persistence of clonally expanded $\mathrm{T}$ cells in patients with polymyositis. Ann Neurol,56:867-72.

[72] Bank I, Miranda AF, Chess L (2001). Mechanisms of cell-mediated myocytotoxicity in the peripheral blood of patients with inflammatory myopathies. J Clin Immunol,21:328-34.
Hoeppli RE, Pesenacker AM (2019). Targeting Tregs in Juvenile Idiopathic Arthritis and Juvenile Dermatomyositis-Insights From Other Diseases. Front Immunol, 10:46.

[74] Banica L, Besliu A, Pistol G, Stavaru C, Ionescu R, Forsea AM et al. (2009). Quantification and molecular characterization of regulatory $\mathrm{T}$ cells in connective tissue diseases. Autoimmunity,42:41-9.

[75] Allenbach Y, Chaara W, Rosenzwajg M, Six A, Prevel N, Mingozzi F et al. (2014). Th1 response and systemic treg deficiency in inclusion body myositis. PLoS One,9:e88788.

[76] Antiga E, Kretz CC, Klembt R, Massi D, Ruland V, Stumpf C et al. (2010). Characterization of regulatory $\mathrm{T}$ cells in patients with dermatomyositis. J Autoimmun,35:342-50.

[77] Vercoulen Y, Bellutti Enders F, Meerding J, Plantinga M, Elst EF, Varsani H et al. (2014). Increased presence of FOXP3 + regulatory $\mathrm{T}$ cells in inflamed muscle of patients with active juvenile dermatomyositis compared to peripheral blood. PLoS One,9:e105353.

[78] McLane LM, Banerjee PP, Cosma GL, Makedonas G, Wherry EJ, Orange JS et al. (2013). Differential localization of T-bet and Eomes in CD8 T cell memory populations. J Immunol,190:3207-15.

[79] Dzangue-Tchoupou G, Mariampillai K, Bolko L, Amelin D, Mauhin W, Corneau A et al. (2019). CD8+T-bet+ cells as a predominant biomarker for inclusion body myositis. Autoimmun Rev, 18:325-33.

[80] Wilkinson MGL, Radziszewska A, Wincup C, Ioannou Y, Isenberg DA, Manson JJ et al. (2019). Using peripheral blood immune signatures to stratify patients with adult and juvenile inflammatory myopathies. Rheumatology (Oxford).

[81] Aleksza M, Szegedi A, Antal-Szalmas P, Irinyi B, Gergely L, Ponyi A et al. (2005). Altered cytokine expression of peripheral blood lymphocytes in polymyositis and dermatomyositis. Ann Rheum Dis, 64:1485-9.

[82] Yi JS, Russo MA, Weinhold KJ, Guptill JT (2016). Adaptive immune response to therapy in hmger autoantibody myopathy. Muscle Nerve,53:313-7.

[83] Morita R, Schmitt N, Bentebibel SE, Ranganathan R, Bourdery L, Zurawski G et al. (2011). Human blood CXCR5(+)CD4(+) $\mathrm{T}$ cells are counterparts of $\mathrm{T}$ follicular cells and contain specific subsets that differentially support antibody secretion. Immunity,34:108-21.

[84] Espinosa-Ortega F, Gomez-Martin D, Santana-De Anda K, Romo-Tena J, Villasenor-Ovies P, AlcocerVarela J (2015). Quantitative T cell subsets profile in peripheral blood from patients with idiopathic inflammatory myopathies: tilting the balance towards proinflammatory and pro-apoptotic subsets. Clin Exp Immunol, 179:520-8.

[85] Houtman M, Ekholm L, Hesselberg E, Chemin K, Malmstrom V, Reed AM et al. (2018). T-cell transcriptomics from peripheral blood highlights differences between polymyositis and dermatomyositis patients. Arthritis Res Ther,20:188. 
[86] Shimojima Y, Matsuda M, Ishii W, Kishida D, Sekijima Y (2017). T-cell receptor-mediated characteristic signaling pathway of peripheral blood $\mathrm{T}$ cells in dermatomyositis and polymyositis. Autoimmunity,50:481-90.

[87] Zhang M, Srivastava G, Lu L (2004). The pre-B cell receptor and its function during $\mathrm{B}$ cell development. Cell Mol Immunol,1:89-94.

[88] Nemazee D (2017). Mechanisms of central tolerance for B cells. Nat Rev Immunol,17:281-94.

[89] Mackay F, Schneider P, Rennert P, Browning J (2003). BAFF AND APRIL: a tutorial on B cell survival. Annu Rev Immunol,21:231-64.

[90] Crotty S (2014). T follicular helper cell differentiation, function, and roles in disease. Immunity,41:529-42.

[91] Allenbach Y, Arouche-Delaperche L, Preusse C, Radbruch H, Butler-Browne G, Champtiaux $\mathrm{N}$ et al. (2018). Necrosis in anti-SRP(+) and antiHMGCR(+)myopathies: Role of autoantibodies and complement. Neurology,90:e507-e17.

[92] McHugh NJ, Tansley SL (2018). Autoantibodies in myositis. Nat Rev Rheumatol,14:290-302.

[93] Ray A, Amato AA, Bradshaw EM, Felice KJ, DiCapua DB, Goldstein JM et al. (2012). Autoantibodies produced at the site of tissue damage provide evidence of humoral autoimmunity in inclusion body myositis. PLoS One, 7:e46709.

[94] Krystufkova O, Vallerskog T, Helmers SB, Mann H, Putova I, Belacek J et al. (2009). Increased serum levels of B cell activating factor (BAFF) in subsets of patients with idiopathic inflammatory myopathies. Ann Rheum Dis,68:836-43.

[95] Krystufkova O, Hulejova H, Mann HF, Pecha O, Putova I, Ekholm L et al. (2018). Serum levels of Bcell activating factor of the TNF family (BAFF) correlate with anti-Jo-1 autoantibodies levels and disease activity in patients with anti-Jo-1positive polymyositis and dermatomyositis. Arthritis Res Ther,20:158.

[96] Baek A, Park HJ, Na SJ, Shim DS, Moon JS, Yang Y et al. (2012). The expression of BAFF in the muscles of patients with dermatomyositis. J Neuroimmunol,249:96-100.

[97] Krystufkova O, Barbasso Helmers S, Venalis P, Malmstrom V, Lindroos E, Vencovsky J et al. (2014). Expression of BAFF receptors in muscle tissue of myositis patients with anti-Jo-1 or anti-Ro52/antiRo60 autoantibodies. Arthritis Res Ther,16:454.

[98] McIntyre D, Zuckerman NS, Field M, Mehr R, Stott DI (2014). The $\mathrm{V}(\mathrm{H})$ repertoire and clonal diversification of $\mathrm{B}$ cells in inflammatory myopathies. Eur J Immunol,44:585-96.

[99] Bradshaw EM, Orihuela A, McArdel SL, Salajegheh M, Amato AA, Hafler DA et al. (2007). A local antigen-driven humoral response is present in the inflammatory myopathies. J Immunol, 178:547-56.

[100] Radke J, Koll R, Preusse C, Pehl D, Todorova K, Schonemann C et al. (2018). Architectural B-cell organization in skeletal muscle identifies subtypes of dermatomyositis. Neurol Neuroimmunol
Neuroinflamm,5:e451.

[101] Salajegheh M, Pinkus JL, Amato AA, Morehouse C, Jallal B, Yao Y et al. (2010). Permissive environment for B-cell maturation in myositis muscle in the absence of B-cell follicles. Muscle Nerve,42:576-83.

[102] Greenberg SA, Bradshaw EM, Pinkus JL, Pinkus GS, Burleson T, Due B et al. (2005). Plasma cells in muscle in inclusion body myositis and polymyositis. Neurology,65:1782-7.

[103] Sasaki H, Takamura A, Kawahata K, Takashima T, Imai K, Morio T et al. (2019). Peripheral blood lymphocyte subset repertoires are biased and reflect clinical features in patients with dermatomyositis. Scand J Rheumatol,48:225-9.

[104] Dzangue-Tchoupou G, Allenbach Y, Preusse C, Stenzel W, Benveniste O (2019). Mass cytometry reveals an impairment of $\mathrm{B}$ cell homeostasis in antisynthetase syndrome. J Neuroimmunol,332:212-5.

[105] Piper CJM, Wilkinson MGL, Deakin CT, Otto GW, Dowle S, Duurland CL et al. (2018). CD19(+)CD24(hi)CD38(hi) B Cells Are Expanded in Juvenile Dermatomyositis and Exhibit a ProInflammatory Phenotype After Activation Through Toll-Like Receptor 7 and Interferon-alpha. Front Immunol,9:1372.

[106] Kikuchi Y, Koarada S, Tada Y, Ushiyama O, Morito F, Suzuki N et al. (2001). Difference in B cell activation between dermatomyositis and polymyositis: analysis of the expression of RP105 on peripheral blood B cells. Ann Rheum Dis, 60:1137-40.

[107] Li W, Tian X, Lu X, Peng Q, Shu X, Yang H et al. (2016). Significant decrease in peripheral regulatory B cells is an immunopathogenic feature of dermatomyositis. Sci Rep,6:27479.

[108] Hervier B, Perez M, Allenbach Y, Devilliers H, Cohen F, Uzunhan Y et al. (2016). Involvement of NK Cells and NKp30 Pathway in Antisynthetase Syndrome. J Immunol, 197:1621-30.

[109] Collison J (2016). Inflammatory myopathies: NK cell function linked to antisynthetase syndrome. Nat Rev Rheumatol,12:562.

[110] Pachman LM, Fedczyna TO, Lechman TS, Lutz J (2001). Juvenile dermatomyositis: the association of the TNF alpha-308A allele and disease chronicity. Curr Rheumatol Rep,3:379-86.

[111] Throm AA, Alinger JB, Pingel JT, Daugherty AL, Pachman LM, French AR (2018). Dysregulated NK cell PLCgamma2 signaling and activity in juvenile dermatomyositis. JCI Insight,3.

[112] Benveniste O, Stenzel W, Hilton-Jones D, Sandri M, Boyer O, van Engelen BG (2015). Amyloid deposits and inflammatory infiltrates in sporadic inclusion body myositis: the inflammatory egg comes before the degenerative chicken. Acta Neuropathol,129:611-24.

[113] Liu Y, Gao Y, Yang J, Shi C, Wang Y, Xu Y (2018). MicroRNA-381 reduces inflammation and infiltration of macrophages in polymyositis via downregulating HMGB1. Int J Oncol,53:1332-42.

[114] Rostasy KM, Piepkorn M, Goebel HH, Menck S, Hanefeld F, Schulz-Schaeffer WJ (2004). 
Monocyte/macrophage differentiation in dermatomyositis and polymyositis. Muscle Nerve,30:225-30.

[115] Roos A, Preusse C, Hathazi D, Goebel HH, Stenzel W (2019). Proteomic Profiling Unravels a Key Role of Specific Macrophage Subtypes in Sporadic Inclusion Body Myositis. Front Immunol, 10:1040.

[116] Yasin SA, Schutz PW, Deakin CT, Sag E, Varsani H, Simou S et al. (2019). Histological heterogeneity in a large clinical cohort of juvenile idiopathic inflammatory myopathy: analysis by myositis autoantibody and pathological features. Neuropathol Appl Neurobiol,45:495-512.

[117] Etzerodt A, Moestrup SK (2013). CD163 and inflammation: biological, diagnostic, and therapeutic aspects. Antioxid Redox Signal,18:2352-63.

[118] Enomoto Y, Suzuki Y, Hozumi H, Mori K, Kono M, Karayama M et al. (2017). Clinical significance of soluble CD163 in polymyositis-related or dermatomyositis-related interstitial lung disease. Arthritis Res Ther,19:9.

[119] Greenberg SA, Pinkus JL, Pinkus GS, Burleson T, Sanoudou D, Tawil R et al. (2005). Interferonalpha/beta-mediated innate immune mechanisms in dermatomyositis. Ann Neurol,57:664-78.

[120] Lopez de Padilla CM, Vallejo AN, McNallan KT, Vehe R, Smith SA, Dietz AB et al. (2007). Plasmacytoid dendritic cells in inflamed muscle of patients with juvenile dermatomyositis. Arthritis Rheum,56:165868.

[121] Greenberg SA, Pinkus GS, Amato AA, Pinkus JL (2007). Myeloid dendritic cells in inclusion-body myositis and polymyositis. Muscle Nerve,35:17-23.

[122] Pinal-Fernandez I, Casal-Dominguez M, Derfoul A, Pak K, Plotz P, Miller FW et al. (2019). Identification of distinctive interferon gene signatures in different types of myositis. Neurology,93:e1193-e204.

[123] Mascarenhas S, Avalos B, Ardoin SP (2012). An update on stem cell transplantation in autoimmune rheumatologic disorders. Curr Allergy Asthma Rep, 12:530-40.

[124] Squillaro T, Peluso G, Galderisi U (2016). Clinical Trials With Mesenchymal Stem Cells: An Update. Cell Transplant,25:829-48.

[125] Wang D, Zhang H, Cao M, Tang Y, Liang J, Feng X et al. (2011). Efficacy of allogeneic mesenchymal stem cell transplantation in patients with drug-resistant polymyositis and dermatomyositis. Ann Rheum Dis, $70: 1285-8$.

[126] Ankrum JA, Ong JF, Karp JM (2014). Mesenchymal stem cells: immune evasive, not immune privileged. Nat Biotechnol,32:252-60.

[127] Lee NK, Na DL, Chang JW (2018). Killing two birds with one stone: The multifunctional roles of mesenchymal stem cells in the treatment of neurodegenerative and muscle diseases. Histol Histopathol,33:629-38.

[128] Denny MF, Yalavarthi S, Zhao W, Thacker SG, Anderson M, Sandy AR et al. (2010). A distinct subset of proinflammatory neutrophils isolated from patients with systemic lupus erythematosus induces vascular damage and synthesizes type I IFNs. J Immunol, 184:3284-97.

[129] Villanueva E, Yalavarthi S, Berthier CC, Hodgin JB, Khandpur R, Lin AM et al. (2011). Netting neutrophils induce endothelial damage, infiltrate tissues, and expose immunostimulatory molecules in systemic lupus erythematosus. J Immunol,187:538-52.

[130] Zhang S, Shu X, Tian X, Chen F, Lu X, Wang G (2014). Enhanced formation and impaired degradation of neutrophil extracellular traps in dermatomyositis and polymyositis: a potential contributor to interstitial lung disease complications. Clin Exp Immunol,177:134-41.

[131] Zhang S, Shen H, Shu X, Peng Q, Wang G (2017). Abnormally increased low-density granulocytes in peripheral blood mononuclear cells are associated with interstitial lung disease in dermatomyositis. Mod Rheumatol,27:122-9.

[132] Danieli MG, Calcabrini L, Calabrese V, Marchetti A, Logullo F, Gabrielli A (2009). Intravenous immunoglobulin as add on treatment with mycophenolate mofetil in severe myositis. Autoimmun Rev,9:124-7.

[133] Majithia V, Harisdangkul V (2005). Mycophenolate mofetil (CellCept): an alternative therapy for autoimmune inflammatory myopathy. Rheumatology (Oxford),44:386-9.

[134] Pisoni CN, Cuadrado MJ, Khamashta MA, Hughes GR, D'Cruz DP (2007). Mycophenolate mofetil treatment in resistant myositis. Rheumatology (Oxford), 46:516-8.

[135] Rowin J, Amato AA, Deisher N, Cursio J, Meriggioli MN (2006). Mycophenolate mofetil in dermatomyositis: is it safe? Neurology,66:1245-7.

[136] Kotani T, Takeuchi T, Makino S, Hata K, Yoshida S, Nagai K et al. (2011). Combination with corticosteroids and cyclosporin-A improves pulmonary function test results and chest HRCT findings in dermatomyositis patients with acute/subacute interstitial pneumonia. Clin Rheumatol,30:1021-8.

[137] Wilkes MR, Sereika SM, Fertig N, Lucas MR, Oddis CV (2005). Treatment of antisynthetase-associated interstitial lung disease with tacrolimus. Arthritis Rheum,52:2439-46.

[138] Oddis CV, Sciurba FC, Elmagd KA, Starzl TE (1999). Tacrolimus in refractory polymyositis with interstitial lung disease. Lancet,353:1762-3.

[139] Mitsui T, Kuroda Y, Ueno S, Kaji R (2011). The effects of FK506 on refractory inflammatory myopathies. Acta Neurol Belg,111:188-94.

[140] Oddis CV, Aggarwal R (2018). Treatment in myositis. Nat Rev Rheumatol,14:279-89.

[141] Tjarnlund A, Tang Q, Wick C, Dastmalchi M, Mann H, Tomasova Studynkova J et al. (2018). Abatacept in the treatment of adult dermatomyositis and polymyositis: a randomised, phase IIb treatment delayed-start trial. Ann Rheum Dis, 77:55-62.

[142] Levine TD (2005). Rituximab in the treatment of dermatomyositis: an open-label pilot study. Arthritis 
Rheum,52:601-7.

[143] Mahler EA, Blom M, Voermans NC, van Engelen BG, van Riel PL, Vonk MC (2011). Rituximab treatment in patients with refractory inflammatory myopathies. Rheumatology (Oxford),50:2206-13.

[144] Lambotte O, Kotb R, Maigne G, Blanc FX, Goujard C, Delfraissy JF (2005). Efficacy of rituximab in refractory polymyositis. J Rheumatol,32:1369-70.

[145] Valiyil R, Casciola-Rosen L, Hong G, Mammen A, Christopher-Stine L (2010). Rituximab therapy for myopathy associated with anti-signal recognition particle antibodies: a case series. Arthritis Care Res (Hoboken),62:1328-34.

[146] Landon-Cardinal O, Allenbach Y, Soulages A, Rigolet A, Hervier B, Champtiaux N et al. (2018). Rituximab in the Treatment of Refractory Anti-HMGCR Immune-mediated Necrotizing Myopathy. J Rheumatol.

[147] Fasano S, Gordon P, Hajji R, Loyo E, Isenberg DA (2017). Rituximab in the treatment of inflammatory myopathies: a review. Rheumatology (Oxford),56:2636.

[148] Narazaki M, Hagihara K, Shima Y, Ogata A, Kishimoto T, Tanaka T (2011). Therapeutic effect of tocilizumab on two patients with polymyositis. Rheumatology (Oxford), 50:1344-6.

[149] Kondo M, Murakawa Y, Matsumura T, Matsumoto O, Taira M, Moriyama M et al. (2014). A case of overlap syndrome successfully treated with tocilizumab: a hopeful treatment strategy for refractory dermatomyositis? Rheumatology (Oxford),53:1907-8.

[150] Oddis CV (2016). Update on the pharmacological treatment of adult myositis. J Intern Med,280:63-74.

[151] Higgs BW, Zhu W, Morehouse C, White WI, Brohawn P, Guo X et al. (2014). A phase 1b clinical trial evaluating sifalimumab, an anti-IFN-alpha monoclonal antibody, shows target neutralisation of a type I IFN signature in blood of dermatomyositis and polymyositis patients. Ann Rheum Dis, 73:256-62.

[152] Chen Z, Wang X, Ye S (2019). Tofacitinib in Amyopathic Dermatomyositis-Associated Interstitial Lung Disease. N Engl J Med,381:291-3.

[153] Moghadam-Kia S, Charlton D, Aggarwal R, Oddis CV (2019). Management of refractory cutaneous dermatomyositis: potential role of Janus kinase inhibition with tofacitinib. Rheumatology (Oxford),58:1011-5.

[154] Kurasawa K, Arai S, Namiki Y, Tanaka A, Takamura Y, Owada T et al. (2018). Tofacitinib for refractory interstitial lung diseases in anti-melanoma differentiation-associated 5 gene antibody-positive dermatomyositis. Rheumatology (Oxford), 57:2114-9.

[155] Paik JJ, Christopher-Stine L (2017). A case of refractory dermatomyositis responsive to tofacitinib. Semin Arthritis Rheum,46:e19.

[156] Kurtzman DJ, Wright NA, Lin J, Femia AN, Merola JF, Patel $\mathrm{M}$ et al. (2016). Tofacitinib Citrate for Refractory Cutaneous Dermatomyositis: An Alternative Treatment. JAMA Dermatol,152:944-5. 